\title{
ICT ENTERTAINMENT APPLIANCES' IMPACT ON DOMESTIC ELECTRICITY CONSUMPTION
}

\author{
Mary Pothitou, ${ }^{1,}$, Richard F. Hanna², Konstantinos J. Chalvatzis ${ }^{3,4}$ \\ ${ }^{1}$ Cranfield Energy, School of Energy, Environment and Agrifood (SEEA), Cranfield University, MK43 0AL, UK \\ ${ }^{2}$ School of Construction Management and Engineering, University of Reading, RG6 6AH, UK \\ ${ }^{3}$ Norwich Business School, University of East Anglia, NR4 7TJ, UK \\ ${ }^{4}$ Tyndall Centre for Climate Change Research, University of East Anglia, NR4 7TJ, UK
}

\begin{abstract}
Increased electricity consumption and environmental impacts of Information Communication Technology (ICT) have been subjects of research since the 1990s. This paper focuses on consumer electronics in households, in particular TVs, computers and their peripherals. ICT accounts for almost $15 \%$ of global domestic electricity use, including waste energy from devices left on standby which is estimated in the EU-27 to contribute 6\% of residential energy demand. In Europe, the household electricity consumption from small electronic appliances, including ICT, increased by 2.5 times in 2011 compared to 1990. Similarly, in the UK, energy demand from electronic devices accounted for $23 \%$ of total household electricity use in 2012, compared to $12 \%$ in 1990 . This is an outcome of the market saturation of new, cheaper ICT entertainment devices, facilitated by marketing strategies which identify new needs for consumers, as charted by the review of market growth in this paper. New increasingly portable laptops, smart phones and tablets with wireless connectivity allow householders to perform a wider range of activities in a wider range of locations throughout the home, such as social networking while the television is active.
\end{abstract}

We suggest that policies which consider how to increase the energy efficiency of ICT devices alone are unlikely to be successful since effective strategies need to address how the drivers which have developed around the use of ICT can be adapted in order to conserve electricity in households. A range of policy solutions are discussed, including feedback, public information campaigns, environmental 
education, energy labelling, bans of, or taxation on the least efficient products as well as the use of a TV as central hub to perform the existing functions of multiple devices.

Keywords: ICT devices, TVs, computers, social practices, household energy savings

*Corresponding author: E-mail address: marypothitou@yahoo.com; m.pothitou@pgr.reading.ac.uk (M. Pothitou). Current Address: Technologies for Sustainable Built Environments (TSBE) Centre, University of Reading, United Kingdom.

\section{INTRODUCTION}

Since the early 1990s, Information and Communication Technology (ICT) has been studied owing to its environmental implications (e.g. raw materials' extraction, use of chemical materials and their electronic waste disposal) and impact on electricity consumption. Extensive research on energy impacts specifically has been carried out since these studies generally indicate the environmental effects and the direct impact of ICT equipment on electricity consumption, considering also standby energy use [1]. The International Energy Agency (IEA) [2], argues that between 1990 and 2008, electricity consumption with regard to ICT (including consumer electronics), in the residential sector, increased globally by approximately $7 \%$ per annum. Future trends foresee a further $250 \%$ growth in ICT electricity use by 2030 , despite enhancements predicted in the energy efficiency of electronic equipment [2, p. 237]. Therefore, the environmental implications from ICT equipment were a focus for research, particularly from the late 1990s to the early 2000s, when the rise of the internet created a 'new economy'. An interest of more recent empirical studies has been motivated by the potential reduction of greenhouse gas emissions which ICT could induce [3]. 
According to Ropke and Christensen [1], the concept of ICT, despite its wider applicability, is usually associated with products and services relevant to entertainment (e.g. consumer electronics such as TVs, computers, radios, music, and console games), communication (e.g. mobile phones) and administrative tasks (e.g. word-processing and calculations). The integration of entertainment devices into a broad variety of social practices in daily life, and the implications for domestic electricity demand, is reviewed in this paper. Currently, ICT is responsible for nearly $15 \%$ of global electricity consumption in the residential sector [2]. IEA [2] anticipates that electricity consumption from these products will double by 2022 and triple by 2030, which corresponds to 1700 TWh by 2030, under a business as usual (BAU) scenario.

The ICT sector is contributing significantly to economies worldwide though increased ownership of personal computers, mobile phones and, in turn, connection to the internet. Between 2000 and 2010, the number of internet users per 100 inhabitants doubled in developed countries and increased by $153 \%$ globally, respectively, while $62 \%$ of households had internet access in developed countries, compared to $75 \%$ for the world as a whole [1].

The aim of this paper is to critically review the role of television and computers in increasing electricity consumption in households, and discuss strategies to address key challenges with reducing residential electricity use from ICT. To achieve this, different perspectives are integrated from market economics, psychology, social practice theory, and empirical energy monitoring studies.

Section 2 sets out the methodological approach for conducting a literature review based on different disciplinary perspectives. The findings of the literature review are presented in Sections 3 to 5. The first output from the review discussed in Sections 3.1 to 3.3 draws upon a comparison of literature on domestic entertainment appliances' energy use at a European scale and studies conducted at a country scale, in particular the United Kingdom, the United States and Australia. Sections 3.4 
details further distinct output from the review, chronicling the history of the market growth of ICT entertainment appliances. Section 4 considers drivers of ICT energy use in households, and specifically the social practices that have developed around these new technologies. Section 5 forms the final component of the review, presenting a critique of the relative strengths and weaknesses of existing and potential strategies aimed at addressing increased electricity usage from ICT devices in the residential sector. The final section interprets the findings with respect to interdisciplinary perspectives considered in this review.

\section{Methodology}

This review follows a systematic, rapid evidence assessment approach, which reflects the standard methodology adopted by the UK Energy Research Centre for technology and policy assessments (Speirs et al., 2015), and recent guidance by Defra on the production of more efficient systematic reviews for the environmental sciences (Defra, 2015). In our study, relevant literature was identified in the field of domestic energy demand for ICT entertainment appliances, following a threestep procedure similar to Kamilaris et al. [4], comprising successive stages of (1) conducting a keyword search; (2) identifying common themes and grouping relevant literature by theme; and (3) selecting a final sample of research studies for detailed review.

Initially, keywords grouped under different categories related to the research topic (Table 1) were combined with Boolean operators to identify relevant academic papers in Science Direct and Web of Knowledge, while relevant grey literature was extracted from Google Scholar and Scopus using identical keyword searches [4,5]. The criteria for extracting 
relevant literature was that retrieved documents should be available online, written in English, focus on the UK, European countries, the US or Australia, and contain material on ICT appliances, specifically televisions or the personal computer. In addition, articles were considered relevant if they pertained to one or more of the following: (1) the energy consumption or demand of these appliances in the residential sector; (2) social practices or behavioural aspects pertaining to ICT in households; (3) the market development and innovation history of the TV and personal computer; (4) policy recommendations on how to manage energy demand from domestic ICT use.

The second stage was to group the extracted documents according to four broad categories: technology, economics, psychological perspectives and social practices. These categories are based on the viewpoints that the level of household energy consumption is embedded in a complex system which involves technology adoption, behavioural economics, and social as well as psycho-social elements [6,7]. Similar themes were then identified based on this categorization, which had relevance to the research aims, namely: the impact of ICT entertainment devices on residential electricity demand; the influence of market factors on the proliferation of these technologies; the shaping of household energy demanding practices which have emerged through ICT; and regulations and policies aiming to enhance technological efficiency and reduce electricity demand from home entertainment devices; and theoretical perspectives applied to the study of ICT at home.

Table 1. Keywords used to identify relevant literature

\section{Keyword categories}




\begin{tabular}{|c|c|c|c|c|}
\hline Technology & Energy & $\begin{array}{l}\text { Customer } \\
\text { segment } \\
\text { social } \\
\text { dimension }\end{array}$ & $\begin{array}{l}\text { Geographic / } \\
\text { temporal }\end{array}$ & Policy \\
\hline ICT & Energy & Domestic & Europe* & regulations \\
\hline "Information & electricity & household & UK & policies \\
\hline Communication & power & residential & United & standards \\
\hline Technology" & use & dwelling & Kingdom & Energy Star \\
\hline "consumer & demand & home & US & label* \\
\hline electronics" & consumption & & United States & feedback \\
\hline appliance & saving & “social & Australia & "information \\
\hline device & “energy & practices" & & campaign" \\
\hline "entertainment & efficen*" & attitudes & market & "environmental \\
\hline appliance" & standby & habits & history & education" \\
\hline "entertainment & MEL & behaviour* & invention & ban \\
\hline device" & "miscellaneous & psychology & innovation & $\operatorname{tax}$ \\
\hline laptops & electrical load" & & diffusion & smart meter \\
\hline computer & kilowatt & & "market & Ecodesign \\
\hline $\mathrm{PC}$ & & & introduction" & \\
\hline
\end{tabular}




\begin{tabular}{|l|l|l|l|l|}
\hline television & & & & \\
TV & & & & \\
Internet & & & & \\
\hline
\end{tabular}

In the final step, we examined the sources in each theme one by one, reviewing and analyzing each study separately, recording its summary and relevance to the identified themes. Through this procedure, we selected the 15-20 most relevant and instructive sources for each theme, obtaining 83 documents in total for detailed consideration in this review.

It is beyond the scope of this paper to consider the wider, life cycle energy consumption from the manufacture or disposal of ICT entertainment appliances. We focus on the direct electricity consumption of TVs and PCs in households, which is supported by several review and empirical studies demonstrating that these devices have the highest impact on electricity consumption from the residential sector compared to other ICT entertainment appliances (8, 77). A recent study by Coleman et al. [8] which is based on fourteen UK households demonstrates that desktop computers together with televisions are the most significant power consuming devices, mostly in the active mode, also contributing to the highest electricity use in households. Similarly, the US Department of Energy estimates that televisions represent the largest miscellaneous electrical load (MEL) in US households, accounting for $22 \%$ of total annual energy demand from domestic MELs, or $4 \%$ of total residential electricity consumption [77]. Moreover, the contribution of TV watching and computer use in households to aggregate electricity demand is substantial because these appliances are widely used, while much TV watching occurs simultaneously (particularly on weekday evenings) across multiple households on a national scale with implications for 
system-wide demand management $[9,10,11]$. This aggregate affect is compounded by increasing rates of TV and computer ownership per household [12,13,14].

\section{HOUSEHOLD APPLIANCES AND ELECTRICITY CONSUMPTION}

\subsection{BACKGRound: Classifications AND MOST COMMON PATTERnS}

Across the EU27, household electricity use accounts for almost a quarter of total electricity consumption, similar to Australia, whereas in the US and UK, the equivalent proportion is around 30\%, which is above the global average (see Table 1). The corresponding residential electricity consumption per person ranges from $1.6 \mathrm{MWh} / \mathrm{capita} / \mathrm{year}$ in the EU27 to 4.5 $\mathrm{MWh} /$ capita/year in the US, compared to the global average of $2.5 \mathrm{MWh} /$ capita/year [15].

Table 2. Residential electricity consumption (adapted from Kelly [15])

\begin{tabular}{|c|c|c|c|c|c|}
\hline & US & Australia & UK & EU27 & Global \\
\hline $\begin{array}{c}\text { (\%) of total } \\
\text { residential } \\
\text { electricity } \\
\text { consumption }\end{array}$ & 31 & 23 & 29 & 24 & 27 \\
\hline $\begin{array}{c}\text { Residential } \\
\text { electricity use } \\
(\mathrm{MWh} / \text { capita/year })\end{array}$ & 4.5 & 2.8 & 1.9 & 1.6 & 2.5 \\
\hline
\end{tabular}


Electrical appliances and devices impact on household electricity consumption through the electric power that they consume, based on the amount of time each appliance is in use and the consumption mode. Electric space and water heating can make the largest contribution to direct household energy consumption, where present in UK households (Figure 1). However, electric heating supplies only a small proportion of UK dwellings, since the principal source of heating in the UK is from natural gas. Figure 1 does not show energy consumption from air-conditioning due to its marginal presence in the UK residential sector (UCL, 2015). Across Europe, energy use per household from air-conditioning varies according to climate and can range from approximately $150 \mathrm{KWh} /$ year in Vienna to $1400 \mathrm{KWh} / \mathrm{year}$ in Athens(Henderson, 2005).

The UK household electricity survey (source) identified that, excluding electric heating, the highest consuming appliances were plasma TVs, lighting, and audiovisual sites (i.e. all ICT devices linked to and used around TV sets). Household appliances are divided into four categories by Firth et al. [16]:

- continuous appliances which consume a constant amount of electricity;

- standby appliances which are not being used actively but are still consuming electricity (e.g. televisions which can operate in three basic states: in use; on standby; or turned off; while laptops can also operate in idle or sleep mode (see Table 2));

- cold appliances which are in continuous use, while their electricity consumption is variable; and

- active appliances, which are those without standby mode and can be switched off so that they do not use any electricity (e.g. lights and kettles). 
Table 3. Electrical appliance power state (adapted from Koomey [17]).

\begin{tabular}{l|l|l|l|l|}
\hline Active & Idle & Sleep & Standby & Disconnect \\
\hline $\begin{array}{l}\text { The power } \\
\text { button is in } \\
\text { the } \text { on } \\
\text { position }\end{array}$ & $\begin{array}{l}\text { The operation at } \\
\text { a low speed, } \\
\text { disengaged from } \\
\text { the load }\end{array}$ & $\begin{array}{l}\text { The lowest } \\
\text { power level } \\
\text { between } \text { on } \\
\text { and } \text { off }\end{array}$ & $\begin{array}{l}\text { The power } \\
\text { button is in off } \\
\text { position \& the } \\
\text { unit is plugged } \\
\text { in (powered) }\end{array}$ & $\begin{array}{l}\text { The power button is } \\
\text { in } \text { off position \& the } \\
\text { unit is unplugged (no } \\
\text { powered) }\end{array}$ \\
\hline
\end{tabular}

According to Coleman et al. [8]; Firth et al. [16]; and E3- Equipment Energy Efficiency (E3-EEE) [18], between the aforementioned categories, the most consuming appliances have been identified to be standby and active appliances, based on studies conducted in the UK and Australia, comprising samples of 14 and 72 households in the UK, and 150 residences in Australia, respectively (see Table 3 which also reflects data from the Centre for Sustainable Energy (CSE) [19]. Table 3 shows that televisions (such as LCD and plasma) consume the most power in the category of standby appliances, whereas more recent LED/LCD TVs are considerably more energy efficient [18,20]. 


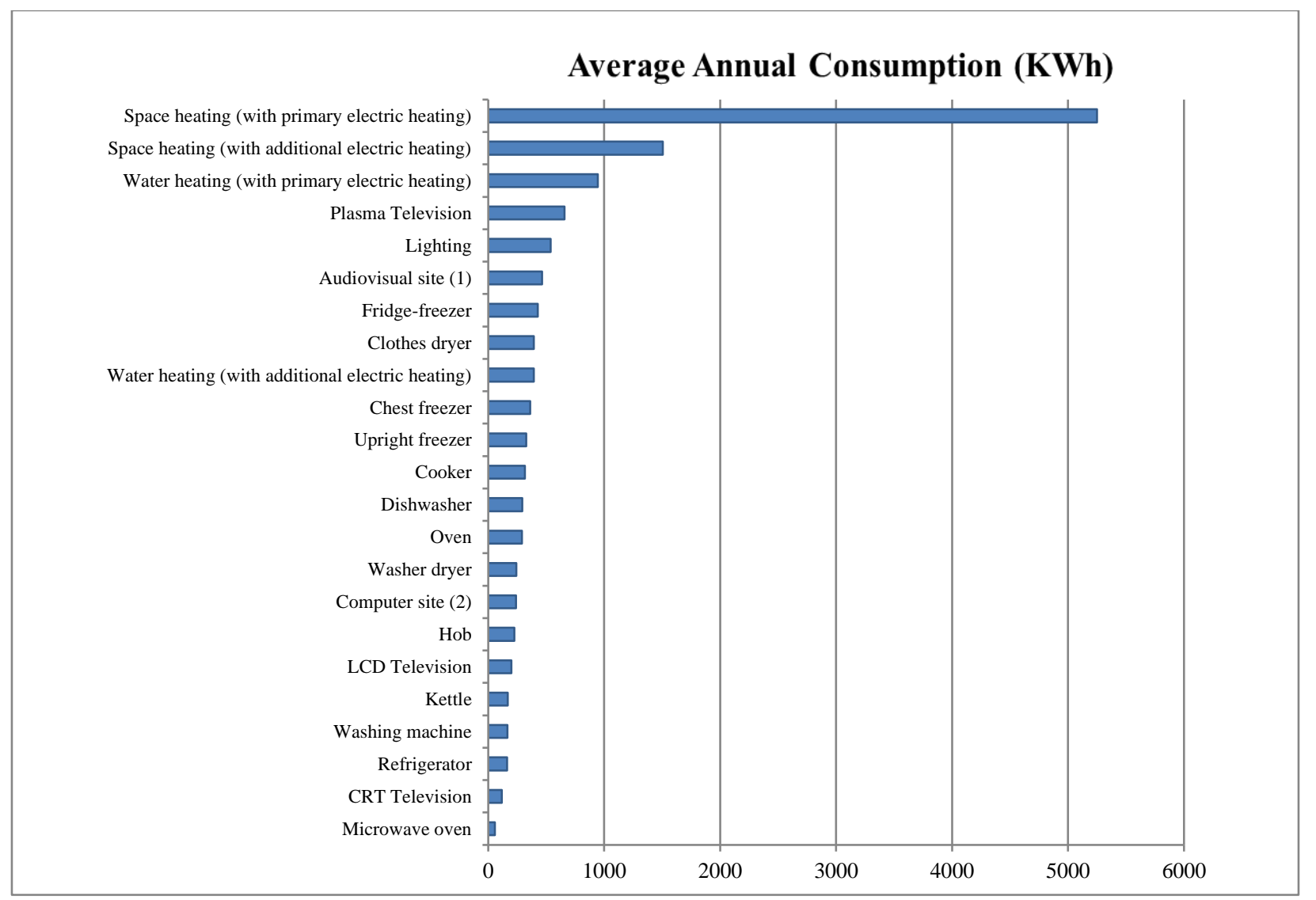

Figure 1. Average annual energy consumption from the UK household electricity survey (DECC, 2014)

1. Audiovisual site includes all products that were typically used around television sets, i.e. DVD players and recorders, VCR, set top boxes, games consoles and home cinema amplifiers and speakers.

2. Computer site includes all computer products that were typically switched on whenever a desktop PC or laptop was used, i.e. screen, printer etc. 
Table 4. Electrical appliance categories and typical appliance power (extracted from: Coleman et al. [8]; CSE [19]; E3EEE [18]; Firth et al. [16]; Williams [21])

\begin{tabular}{|c|c|c|c|c|c|c|c|}
\hline \multicolumn{8}{|c|}{ Appliance categories and typical appliance power } \\
\hline $\begin{array}{l}\text { Appliance } \\
\text { Category }\end{array}$ & $\begin{array}{l}\text { Category } \\
\text { Description }\end{array}$ & Example Appliance & $\begin{array}{l}\text { Typical in-use } \\
\text { power (W) } \\
\text { (Coleman et al., } \\
\text { 2012; CSE, 2014; } \\
\text { Firth et al., 2008; } \\
\text { Williams, 2013) }\end{array}$ & $\begin{array}{l}\text { Typical } \\
\text { standby (W) } \\
\text { (Firth et al., } \\
\text { 2008; } \\
\text { Williams, 2013) }\end{array}$ & $\begin{array}{l}\text { Average on mode } \\
\text { power }(\mathbf{W}) \\
(E 3-E E E, 2011)\end{array}$ & $\begin{array}{l}\text { Average active } \\
\text { standby }(\mathbf{W})^{2} \\
(\text { Coleman et al., } \\
\text { 2012; E3-EEE, } \\
\text { 2011) }\end{array}$ & $\begin{array}{l}\text { Average passive } \\
\text { standby }(\mathbf{W})^{3} \\
\text { (Coleman et al., } \\
\text { 2012; E3-EEE, } \\
\text { 2011) }\end{array}$ \\
\hline Continuous & $\begin{array}{l}\text { Continuously } \\
\text { switched on and } \\
\text { constant power } \\
\text { consumption }\end{array}$ & $\begin{array}{l}\text { Clocks } \\
\text { Alarms } \\
\text { Broadband Modems } \\
\text { Wireless router }\end{array}$ & $\begin{array}{l}5 \\
4 \\
64 \\
7-10\end{array}$ & $\begin{array}{l}- \\
- \\
-\end{array}$ & $\begin{array}{l}- \\
- \\
-\end{array}$ & $\begin{array}{l}1.1 \\
2.1 \\
8.3 \\
5.4\end{array}$ & $\begin{array}{l}- \\
- \\
-\end{array}$ \\
\hline Standby & $\begin{array}{l}\text { Actively switched } \\
\text { on by } \\
\text { householders. } \\
\text { When not in use, } \\
\text { power } \\
\text { consumption may } \\
\text { be non-zero }\end{array}$ & $\begin{array}{l}\text { Televisions - CRT } \\
\text { Televisions - LCD } \\
\text { Televisions - LED/LCD }{ }^{1} \\
\text { Televisions - Plasma } \\
\text { Set-top boxes } \\
\text { Audio Hi-Fi } \\
\text { Smart Phone (charge) } \\
\text { Desktop Computer } \\
\text { Laptop Computer } \\
\text { Tablet (charge) } \\
\text { Printer - Inkjet } \\
\text { Games Console } \\
\text { Video, DVD or CD }\end{array}$ & $\begin{array}{l}64-67 \\
100-200 \\
- \\
250-450 \\
17 \\
14 \\
2.5-5 \\
77-150 \\
20-56.4 \\
10 \\
11.7 \\
42.9-190 \\
20-60\end{array}$ & $\begin{array}{l}3.5 \\
2.0 \\
- \\
2.7 \\
8.0 \\
8.2 \\
2.8 \\
7.1 \\
28 \text { (idle) } \\
- \\
- \\
- \\
-\end{array}$ & $\begin{array}{l}68 \\
83 \\
58 \\
112 \\
10 \\
- \\
- \\
88 \\
32 \\
- \\
- \\
- \\
-\end{array}$ & $\begin{array}{l}- \\
- \\
- \\
- \\
- \\
17 \\
- \\
- \\
- \\
3.5 \\
2.3 \\
38.4-45 \\
-\end{array}$ & $\begin{array}{l}3.8-6.9 \\
1.1-3.5 \\
3.1 \\
4 \\
5.2 \\
8 \\
- \\
- \\
11.4 \\
- \\
- \\
5.4-8.8 \\
-\end{array}$ \\
\hline Cold & $\begin{array}{l}\text { Continuously } \\
\text { switched on and } \\
\text { power }\end{array}$ & $\begin{array}{l}\text { Fridges / Freezers / Fridge- } \\
\text { freezer }\end{array}$ & $80-250$ & 8.8 & - & - & - \\
\hline
\end{tabular}


on by

\section{Kettles}

householders.

Electric hobs

When not in use,

power

Washing Machines

\section{Electric Showers}

Lighting - CFL

zero.

\begin{tabular}{l|l|l|l|l|}
$2000-3000$ & - & - & - & - \\
\hline 2500 & - & - & - & - \\
2000 & - & - & 5.9 & - \\
\hline $4000-9000$ & - & - & - & - \\
$9-13$ & - & - & - & - \\
$60-100$ & - & - & - & -
\end{tabular}

60-100

Lighting - Incandescent

${ }^{1}$ The most energy efficient LED/LCD TVs with an Energy Star label available in 2015 have lower power ratings ranging from 10W to 26W for screen sizes of 16 to 32 inches, and from $30 \mathrm{~W}$ to $42 \mathrm{~W}$ for screen sizes of 39 to 50 inches [20].

${ }^{2}$ Active standby: "The power used when the appliance is on, but not performing its main function (e.g. when a DVD recorder is on but not recording or playing)" [8, p.63]

${ }^{3}$ Passive standby: "The power used when the appliance is not performing its main function, but is in a state waiting to be switched on or is performing a secondary function (e.g. when a television has been switched off by the remote control)" [8, p.63] 


\subsection{HiSTORICAL REVIEW OF EUROPEAN HOUSEHOLD ENTERTAINMENT APPLIANCES' CONSUMPTION}

A chronological review of the electricity consumption from domestic appliances in European countries tracks changes in household electricity consumption since 1973. In the early 1980s, the most consuming appliances were white goods (e.g. washing machines and refrigerators), while nowadays the appliances which impact on an increase of electricity usage are household ICT and small kitchen devices [22,23]. For example, the typical electricity use of a TV set-top box is similar to that of an Energy Star rated refrigerator [24], while computing electricity consumption per residence is usually greater than the total energy consumed by washing clothes/dishes [25].

Between 1973 and 1998 residential electricity demand in the IEA-11 doubled: two-thirds of this growth was due to electrical appliances. During the 2000s, the $2 \%$ per annum growth in electricity consumption from electrical appliances and lighting in half of the EU-27 countries (compared to 1.7\% per annum on average for all of the EU) has been attributed by Lapillonne et al. [26] to several factors across a number of European countries, such as Estonia and Latvia, which experienced accelerated economic growth and increased ownership of domestic appliances.

By 2009, typically in the EU, electrical appliances (e.g. cold appliances such as fridges and freezers, and washing appliances; ICT equipment including TVs, computers; and other small appliances) and lighting contributed over $60 \%$ of total residential electricity demand. In particular, small appliances doubled their share of household electricity consumption from $18 \%$ in 1990 to $39 \%$ in 2009. The electricity consumed for small appliances per household is 2.5 times higher in 2011 (790 $\mathrm{kWh} / \mathrm{annum})$ than in 1990 (310 kWh/annum). While there was increased market penetration of televisions over this time, electricity demand from TVs actually fell gradually until the year 2000, prior to a growth in their contribution to electricity demand caused by a proliferation in the purchase of larger TVs [26,27].

In 2007, electricity consumed by TVs in the member states of the EU-27 was assessed by IEA [2] as 60TWh (54 TWh in on-mode and $6 \mathrm{TWh}$ in stand-by/offmode). This level of energy use is attributed to the increased ownership of TVs per household, without replacing old devices, as well as increases in viewing-time which 
offset improvements in the efficiency of contemporary models. Indeed, from 2006 to 2010, there was a $21 \%$ reduction on average in the energy use per TV set from 219 $\mathrm{kWh} /$ year to $173 \mathrm{kWh} /$ year [28]. Savings from TVs are projected to be around 43 TWh/annum by 2020, due to energy labelling and requirements for improved performance.

Nevertheless, TV screen size impacts on increased electricity consumption, as larger screens are more energy intensive. Recently, there has been a strong demand for larger TVs, with 54\% of television purchases in 2013 being for screen sizes of 39 inches or greater [29]. Similarly, in the case of computers, larger screen sizes have become more popular in OECD countries recently, following reductions in the cost of larger LCD monitors (e.g. 19 to 30 inches) [2].

\subsection{HISTORICAL REVIEW OF THE UK'S HOUSEHOLD ENTERTAINMENT APPLIANCES' CONSUMPTION}

At a national scale, and specifically in the UK in 1990, domestic appliances together with lighting, accounted for more than a fifth of annual electricity use, close to a quarter of peak electricity demand, resulting in 40 million tonnes of $\mathrm{CO}_{2}$ emissions [14]. A historical review of household appliances in the UK showed that electricity use in 2002 was 89TWh, twice the figure in 1972 [12]. Thus, increased rates of electronic appliance ownership have led to energy demand from electronics being equivalent to $23 \%$ of total household electricity use in 2012 , rising from $12 \%$ in $1990[73]$.

Televisions, specifically, accounted for $270 \mathrm{KWh} /$ household/year or $73 \%$ of total consumption from residential consumer electronics in 2012, compared to $217 \mathrm{KWh} /$ household/year or $72 \%$ in 1990 [73]. While half of households in Great Britain owned a colour TV set in 1976, the average ownership rate increased to 1.6 sets per home in 1994 [14] and 2.4 TVs per household in 2004 and in 2012 [12,73]. Altogether, electricity consumption from colour televisions was 5.3 TWh in 1987, compared to $7.2 \mathrm{TWh}$ in 1994 . In all years, from 1975 to 2012 , only $2 \%$ to $3 \%$ of all UK households did not own a TV [73].

With respect to computers, the ownership of personal computers was very low in 1982, amounting to only $3 \%$ of the population in the UK. This proportion increased 
sharply so that by $2004,60 \%$ of UK households owned at least one PC. Following the trend with computers, the ownership of printers increased enormously from $0.7 \%$ in 1983 to $58 \%$ in 2004 [13]. Data from DECC [73] reveals that from 2005 to 2012, the number of laptops and printers owned in UK households increased by eight times and two and a half times, respectively. By 2012, there was an average of one laptop and one printer per household in the UK, while only $40 \%$ of households owned desktop computers [73,74,75]. Consequently, between 2000 and 2012, the total energy consumed by computers in the UK domestic sector approximately doubled, due to rapid increases in laptop ownership and Internet access counteracting declining ownership of more energy intensive desktop computers [75]. By 2014, entertainment devices such as TVs and games consoles were responsible for $26 \%$ of domestic electricity use with computing equipment contributing an additional 8\% [36].

Estimates of power used by computers and laptops including different monitor types are shown in Table 4, indicating how energy consumption varies by power mode. Power monitoring has revealed that these devices vary greatly in terms of their energy consumption, depending on whether they are in 'sleep' mode (1.5 to 15 watts) or 'idle' mode (71 to 221 Watts). Laptops' energy consumption was found to be more consistent and lower compared to desktop PCs, for different laptop specifications and across various modes [13]. Based on US Energy Star data presented in Table 4, desktops and CRT monitors have the highest impact on electricity consumption, which also depends on user behaviour patterns [31].

Table 5. Laptops and Desktops power consumption (adapted from Williams [21])

\begin{tabular}{|l|c|c|c|c|}
\hline Device Type & \multicolumn{2}{|c|}{ Power Consumption (Watts) } & & \\
\hline & Active & Idle & Sleep & Off \\
\hline Desktop & 112.1 & 57.3 & 5.0 & 2.8 \\
\hline Laptop & 56.4 & 28.0 & 3.7 & 1.2 \\
\hline LCD/LED Monitor & 19.5 & 19.5 & 0.5 & 0.4 \\
\hline CRT Monitor & 73.0 & 73.0 & 3.9 & 0.3 \\
\hline
\end{tabular}

*Based on data from US Energy Star [32,33].

More recent measurements of operating power from a sample of electrical appliances (excluding white goods) in Australia also found considerable variations for 
given devices, ranging from 24 to 36 watts for a laptop, compared to 20 to 320 watts for LCD TV, and 215 to 613 watts for a plasma TV [34].

In addition to the operating power, household electrical appliances also contribute significantly to waste energy through standby consumption. According to a study of 1,300 households conducted in 12 European countries ${ }^{1}$ by De Almeida et al. [35], standby use corresponds to around $11 \%$ of the total energy consumption in the residential sector (not including space and water heating), equivalent to approximately 40W per household. This is consistent with studies conducted in Germany, Holland, the United States, and Australia which revealed that roughly $10 \%$ of domestic electricity use in these countries is due to standby power [15,34].

In the UK, specifically, standby demand can range from $9 \%$ to $16 \%$ of residential electricity consumption, based on the 'Household Electricity Survey' sample of 251 homes [36]. Another study sample of fourteen UK homes shows that on average, ICT appliances in active mode accounted for around $23 \%$ of domestic electricity use, while devices left on standby mode contributed an additional 7\% of the total [8].

Whereas TVs consume less energy on standby mode (1 to 4 Watts) than when they are in active use (100+ Watts), standby operation accounts for $9 \%$ of the total electricity consumption from the whole UK television stock, due to devices continuing to draw energy even when people are not watching [13]. EST [12] notes that televisions and set top boxes are designed to be left on standby so that television programmes may be recorded when residents are away from home, or for automatic software downloads [12,13]. Similarly, a wide range of desktop computers do not have a manual off button on their processor unit, and consequently, the only way to turn them off completely is to unplug them [13]. Approximately $40 \%$ of British households leave games consoles on or in standby mode when they are not using them actively, while $75 \%$ of these households with a spare TV leave it on standby [36]. By way of comparison, in another European country (Spain), standby losses, as a proportion of the energy used by appliances in their active mode, accounted for around $6.5 \%$ to $12.9 \%$ (equivalent to $216.2-240 \mathrm{GWh} /$ year) for televisions and $22.8 \%$ (equivalent to $96.3 \mathrm{GWh} /$ year) for computers, respectively, assuming that each device used 1 Watt when on standby [11].

\footnotetext{
${ }^{1}$ Belgium, Bulgaria, Czech Republic, Denmark, France, Germany, Greece, Hungary, Italy, Norway, Portugal and Romania
} 


\subsection{THE MARKET GroWTH OF HOME EnTERTAinMent APPLIANCES}

Electrical appliances were first manufactured and distributed in the US and Europe early in the $20^{\text {th }}$ Century, but it was only after the Second World War that they became widespread in households. In the US, these domestic technologies evolved around the private suburban home, family life and telephone, radio and films. Across countries in Europe, as well as US and Australia, televisions and computers have been marketed in such a way as to promote their capacity to serve and sustain family unity, to counteract initial fears that households may be divided by the new myriad practices enabled by such devices [37].

Until recently, the predominant television technology has been the cathode ray tube (CRT) which was invented around 1890. From the late 1930s black and white televisions were available on the mass market, while colour broadcasting became commonplace in the 1960s [2]. The rise of television in the 1950s and declining box office takings in the cinema can be linked to the extensive promotion of television in the USA and Great Britain as a way of bringing the cinematic experience into households, so that advertisers used terms such as 'home theatre' [37,38]. This trend has continued with the rise of large, flat screen TVs and surround-sound, for example.

Given the accelerating popularity of flat screen TVs with their enhanced picture quality, and the availability of big screen sizes requiring much less depth, sales of LCD TVs first exceeded those of their CRT counterparts in the UK in 2006 [13], and in the EU in 2007 [39]. This was due to the advantages of LCD over plasma TV screens of being considerably lighter, cheaper, with potentially longer lifetimes [13]. Flat screen TVs comprised 100\% of all television sales in the EU-15 in 2010 [28]. Falling retail prices for flat TV screens have brought them into the affordability zone of the typical consumer, who is more likely to purchase them for aspirational reasons rather than considering how much they cost to run [13]. In 2007, small screen sizes (14-26 inches) still comprised over half the EU market share, with medium screen sizes (27-39 inches) approaching a third of the market [40].

Across the EU, the transition to flat screen TVs has been further consolidated following the switch from terrestrial to digital transmission and high-resolution television (HDTV) [40,41]. Modern, more energy intensive types of TV screens, the provision of standby, linked devices, and the marketing accompanying these new 
technologies and services, have all shaped increased electricity demand for home entertainment $[13,41]$.

TVs, computers and laptops have been manufactured with relatively short lifespans, a phenomenon termed 'product obsolescence', through which advertising strategies are used to persuade consumers to purchase new products in place of appliances which may still be functioning or could still be repaired $[42,43]$. This is achieved through a marketing mechanism known as 'marketer-induced problem recognition', designed to activate dissatisfaction in customers and lead them to perceive that new problems exist which need to be solved by purchasing their products [43, p.28].

Initially, in the case of personal computers, potential customers did not understand which needs could be addressed by owning these products. Subsequently, PC manufacturers effectively induced problem recognition by marketing how computers could improve children's academic abilities and performance at school [43]. Further to this, the laptop and the notebook ${ }^{2}$ computer are two more recent innovations with the laptop first succeeding in the European market in 1985, followed by the US and Japan, while the notebook achieved global success in 1989. Both innovations benefited from a product design which considered what the requirements of the market were, as opposed to the conventional approach of designing products from Research and Development ( R \& D) without taking user needs into account. The product design drew upon an entrepreneurial vision of miniaturised, compatible and portable, personal computers which could be interconnected in a world of distributed computing [82].

Technological improvements, falling prices of new ICT entertainment appliances and greater demand for these products have led, through economies of scale, to increased production volumes and competition, leading to further price reductions and mass market saturation. This has resulted in the ownership of multiple entertainment appliances per household, for example, it is typical for a family to own more than one TV and computer, as well as more than one phone, DVD-player and games console [43].

${ }^{2}$ The notebook was designed to have approximately $30 \%$ of the length of a laptop, $55 \%$ of the width and less than half of the weight, while being completely compatible with IBM. With respect to energy consumption, notebook computers were initially capable of starting up and shutting down faster than laptops with the potential to save power [82]. 


\section{UNDERSTANDING THE DRIVERS OF ICT ENERGY USE}

ICT devices are purchased for use in households in order to contribute to customers' well-being by creating value in the form of knowledge or entertainment [43]. Further to this, everyday activities, namely social practices, in the home have evolved, associated with the use of TVs and computers and other ICT entertainment devices $[1,8]$. Social practices refer to the coordinated and interdependent activities of individuals across time and space, including cooking, eating, sleeping, caring for children and others, leisure and work [78,81]. These practices imply energy consumption through the use of resources, even if people are not conscious of the consumption caused by their daily activities [81].

An empirical study carried out from 2007 to 2008, comprising interviews with 14 Denish households, demonstrates how use of computers and the internet has become intertwined with a whole range of social practices in the home $[1,71,72]$. These practices, categorised in the study by 48 activities across 10 groups $^{3}$ [71,72], have incorporated the new possibilities enabled by ICT, changing the nature of many practices in the process.

'Old ICTs' such as telephone, radio, and television were originally designed for practices whose purpose was defined by these technologies [72]. In contrast, newer ICTs, particular smart phones and portable computers with internet connectivity, have increased accessibility to a wider range of activities [72,79]. This can be exemplified by the use of digital cameras or smart phones to capture pictures of social events, which can then be uploaded and accessed through photo sharing albums on the internet or social networking websites [72].

A more recent study conducted by Kawsar and Brush [84] on 86 households in Belgium, combining monitoring of Internet use with interviews of 18 of these househoulds, revealed that many social practices previously conducted using desktops and laptops are now performed using mobile devices such as tablets and smartphones. Notebly, the study participants favoured these mobile devices over desktops or laptops in particular for social networking, while use of ICT devices was observed in a wide range of locations in the home (including the kitchen and bathroom).

\footnotetext{
${ }^{3}$ The 10 activity categories were: "communication, entertainment, information, purchase and sale, work at home, education, hobbies and volunteer work, administration and finances, domestic work, management of the dwelling, and health" [1, p.354].
} 
Conversely, desktop computers are most likely to be used for special purposes including working from home and Internet gaming [84].

These new ICTs also facilitate the simultaneous use of consumer electronic devices for entertainment, social networking, or to pursue personal interests $[8,44]$. This multiple use of entertainment appliances may manifest itself in various forms, including 'social television', for example, communicating with friends via social networking websites while watching TV, which in turn is being augmented by new, interactive offerings from service providers [8]. Conversely, another study has identified that laptops and desktops are often used by students for watching films and listening to music, therefore displacing the use of TV or hi-fi systems [70].

Important aspects of social practices have been identified with respect to ICT devices in a study based on 14 household interviews in the UK [8]. This study found that the highest electricity consumption from computer use tended to occur in those households where at least one resident worked from home on a regular basis [8]. Since the introduction of the personal computer from the 1980s [72], the boundary between work and leisure has become blurred, facilitated by the market growth of portable and mobile devices [37] and the use of ICT equipment in the home which previously would have been associated with office environments (e.g. printers and scanners) [77]. While the proportion of people who work from home is increasing $14 \%$ of the working age population in Great Britain in 2014 compared to $11 \%$ in 1998 [45] - only 4\% of Europeans (EU-27) worked from home in 2010 [68]. Moreover, the increased ownership of personal computers is fundamentally related to householders' access to the Internet in the home [2].

In addition, the study by Coleman et al. [8] revealed how residents sometimes use ICT appliances to create a comfortable background environment while they are doing other activities, for example by listening to the radio on the television or leaving the television on with the volume muted. According to tests by EST [13], the practice of listening to the radio through a digital television can be 10 to 20 times more energy intensive than listening to a typical digital radio, as it is necessary to keep the television and set top box on (if the digital TV is not integrated). Employing screen blanking, so that the signal for the selected channel is received exclusively in audio, can reduce the electricity consumption of this activity by $75 \%$.

The use of ICT in households varies depending upon whether individuals are adults or children [30]. For example, a study from Denmark indicates that while 
children typically learn how to use computers by playing games on them, adults most often gain their knowledge of computers through their work. ICTs may fall out of fashion quickly, such as games consoles and video players, so that they are rarely used actively but may still be left consuming electricity in standby mode. Some families may integrate more energy efficient, portable computers within household entertainment or information searching activities by keeping them in the living room or kitchen, which may have the effect of encouraging more energy intensive practices involving multiple devices. Alternatively, families may separate desktop computers from other household activities, by placing them in an office-like environment.

Considering that ICT devices offer completely new functionalities in households, consumers have viewed such technologies with a greater interest than those which conflict with or replace existing practices in the home, such as the introduction of washing machines into households. While new technologies may be purchased initially as a status symbol, ICT has reached the point where it is difficult for households to live without these devices and gadgets [30].

Nevertheless, the television itself could actually provide a solution to energy hungry practices which have developed around simultaneous activities using a multiple devices [13]. For example, the TV could become the central device in a household: a television screen can also be used as a computer monitor, for playing computer games and potentially for viewing information from a household smart meter and controlling other devices in the home. The television unit could incorporate in one device additional functions currently provided through the DVD player, set top box, games consoles and so on, to decrease waste energy from separate appliances, each with their own standby modes. Such 'smart' televisions have been trialed by eSESH [56] in 80 households in Moulins, France, where near real-time energy use information is transmitted from a server to a TV Energy Display System. This information is displayed on a dedicated channel and appears by default every time the TV is turned on. 


\section{REDUCING ELECTRICITY USE FROM HOME ENTERTAINMENT APPLIANCES: STRATEGIC APPROACHES}

\subsection{APPROACHES FROM PSYCHOLOGY}

The effect of feedback on household electricity consumption has been extensively researched, with estimates of energy savings typically range from 5\% to $20 \%$ $[46,47,48,49,50]$. Notwithstanding the impact of ICT entertainment devices, ICT may itself provide solutions to managing and reducing residential electricity consumption. Feedback systems based on ICT devices such as smart meters have most potential to be effective in reducing energy use where information is accessible and appealing to householders and provided at a disaggregated or appliance level (Ropke et al., 2010). Mills \& Schleich [51] and Steg [52] support the effectiveness of tailored feedback as a potential measure to raise the quality of knowledge of household energy savings, and the monetary and environmental implications of energy consumption. However, it has been identified by Ellegard \& Palm [53] and Mills \& Schleich [51] that tailored feedback might not alter energy behaviours from highly consuming to more conservative practices, since the impact of householders' energy use on the environment is insufficiently transparent for them to reconsider the effect of their energy practices.

According to EEA [54], the focus of residential energy demand reduction policies (e.g. smart-meter rollout programmes) is mainly on the measure itself, rather than addressing how individuals' energy behaviour and consumption practices might be altered. Achieving the latter could involve assessment of representative demographic target groups for whom specific behavioural measures can be implemented. Such tailored information considers how to better inform residents of their household energy use and in turn reduction options, focusing on personalized advice based on specific household demographics $[53,55]$.

Beyond traditional forms of feedback, the Internet can be used as an alternative medium to provide household energy awareness and management services. The 'Saving Energy in Social Housing with ICT' programme [56] has conducted pilot projects in ten sites across Europe since 2010 with the objective of saving energy in European social housing. The project's Energy Awareness Services (EAS) provide 
feedback on energy consumption so that tenants may have the opportunity to alter their behaviour. For example, tenants in 77 pilot households in Catalonia can access information on their monthly, weekly and hourly electricity use (direct feedback) via an energy web portal, and can compare their energy use with that of other tenants and the average consumption from households in their building (comparative feedback). An additional tool piloted is an 'Energy Management Service' (EMS) which aims to optimise the timing of residential electricity use, and reduce peaks of demand. This has been attempted via mobile devices supplied to households in Linz, Austria, which display energy consumption data in real time from adaptor plugs for each appliance, providing a means for residents to actively manage their energy use by determining which devices are the most consuming [56].

Feedback could be enhanced through public information campaigns, such as the energy savings guide on home entertainment systems provided by the Australian government, including advice for householders on purchase and use of TVs, computers / tablets, games consoles and mobile phones [57]. In order to be successful, public information campaigns aiming to reduce household energy consumption should seek to influence attitudes and behaviour, which could be combined with pricing incentives. Energy companies and government bodies have a role in such campaigns to disseminate knowledge and information to enable householders to alter the energy behaviours [58].

An alternative strategy for motivating households to reduce their energy use is focused on the environmental education of householders involving both parents and children [59]. For a given individual, education may be correlated with a high level of environmental concern, which might in turn determine whether they behave in proenvironmental ways [60]. This is in line with the study by Fell \& Chiu [59] which recommends that environmental education be usefully promoted by policymakers as an instrument to engage communities in environmental issues and particularly to enhance children's role since previous findings from Uzzell [61] show them as 'potential catalysts of environmental change'. However, the results from Fell \& Chiu's [59] study reveal that children were not willing to reduce daily activities which impact on household energy consumption directly (e.g. playing games and watching TV), while the parents' role to encourage their children to reduce home energy use was outweighed by other factors such as their lack of time or concern about the impact on their energy bill. 
A recent analysis of the 'Household Electricity Survey', based on 250 residences in the UK, found that households which were more concerned about climate change actually consumed more electricity overall than those who were less concerned [62]. Furthermore, in a previous study by the same author [63], there does not seem to be any clear relationship between environmental concern and TV ownership in terms of the average number of units owned. For example, those who were 'very concerned' about the environment, owned 2.1 TVs on average, the same number as those who were 'not very concerned'.

\subsection{THE ROLE OF REGULATION}

Interventions targeted at the energy behaviour of householders alone may not be successful in achieving electricity savings without regulations on product efficiency standards. When designing electrical appliances, manufacturers of these products are required by the Eco-design Directive (2005/32/EC), as introduced in August 2010, to ensure that they limit energy consumption and harmful environmental effects throughout the life cycle of the appliances $[28,35]$.

The Ecodesign directive was widened in December 2008 to apply to, for example, TVs, set top-boxes, standby and off-modes, and household lighting. Regulation No. 1275/2008 also extended the Ecodesign Directive to include energy consumption of household ICT devices from standby and off-modes. This regulation sets out maximum limits for the electricity use of these appliances when on standby or in offmode states, which were reduced in 2013 to no greater than $0.5 \mathrm{Watt}$ and 1 Watt for those devices with information or status display [28]. The latest European Commission (EC) proposals ${ }^{4}$ for new Ecodesign regulations would require internetconnected devices, including 'smart' televisions, printers and routers, to switch to a low power standby mode automatically when they are not being used [64].

Nevertheless, the existing EU labelling directive of 1992 (92/75/EEC), updated by the EU Parliament in December 2010, currently covers TVs, white goods, lighting and air conditioning, but needs to be broadened to include other ICT devices, given their substantially increased rates of ownership across EU households [35]. While

\footnotetext{
${ }^{4}$ These proposals are currently subject to scrutiny by Members of the European Parliament and European Union government ministers (EC, 2015) [64].
} 
voluntary energy labelling schemes exist such as Energy Star, an empirical study of households by Coleman et al. [8] revealed that most respondents are not aware of them. Residents in this study had little knowledge about how much energy appliances actually use, but in some cases decisions to buy more energy efficient cold (e.g. fridge and freezer) and wet (e.g. washing machine and dishwasher) appliances had been influenced by an awareness of compulsory energy labels for these products. Moreover, some respondents indicated that they would purchase lower energy consuming ICT devices if mandatory energy labelling was introduced to apply to them. EST [13] and Santiago et al. [10] suggest that sales staff could be trained specifically to help raise consumer knowledge about Energy Star ratings, while regulations could be introduced to make such voluntary schemes compulsory.

White goods have already been subject to more stringent product standards across the EU, whereby the least efficient appliances have been banned. EST [12] recommends that a similar approach could be implemented for ICT devices, for example, the $25 \%$ least energy efficient products in the market could be prohibited at regular intervals, e.g. every 3 to 5 years. This is exemplified by the progressive EU bans of 25 to 100 Watt light bulbs in the EU from 2009 to 2012 [65]. Beyond applying standards to existing products, the energy efficiency of ICT devices could be accelerated through increased investment in Research and Development (R \& D) into these products [12].

Pricing strategies have been proposed that would raise the costs of electricity during periods of peak demand, in order to create a disincentive against using electricity-intensive devices such as TVs and computers at those times. However, such measures are considered to be less effective than energy labelling schemes to increase the quantity of energy efficient devices purchased, or directives which limit how much energy such equipment is designed to consume [10].

Regardless of the contribution of regulations and policies to improving domestic appliance efficiency, the rebound effect may constrain the potential for energy savings through the purchase of efficient devices, either by increasing the quantity of electricity consumed, or due to a higher quality of energy service [54]. Nevertheless, Maxwell et al. [69] suggest that the rebound effect is not of sufficient magnitude to support delays in energy efficiency investments or measures to change behaviour. Moreover, energy efficiency measures can achieve economic, social and environmental benefits beyond energy saving itself. 


\section{Conclusions}

Household entertainment devices, as part of the ICT sector, present a challenging area for policy research on EU countries due to their rapidly increasing impact on household electricity consumption. This rising impact on energy demand at home can be attributed to the increased ownership of affordable, higher performing ICT devices such as TVs, computers and their peripherals. These new technologies, facilitated by the availability of the Internet, have influenced and transformed householders' practices with implications for domestic electricity demand. Smart phones and tablet computers also constitute technologies with a high degree of portability upon which practices in daily life have become dependent on active data connectivity, referred to as the 'always on' society [80]. Since the iPhone was first introduced in 2007 [25], there has been in the US from 2009 to 2013 a growth of $250 \%$ [66] in the number of internet connected smart phones, and a doubling of laptop, tablet and modem connections. This is associated with a $120 \%$ year on year increase in wireless data traffic from smart phones, laptops and tablets between 2010 and 2013 [66]. The energy impact of this internet traffic is considerable: for example, the annual electricity use of streaming an hour of video every week on a smart phone or tablet is equivalent to the yearly electricity use of two energy efficient refrigerators [25].

As a short term measure pending adoption of more energy efficient devices by households over time, electricity use from ICT in the home could be decreased significantly through basic behavioural change actions such as disconnecting devices from their power source $[8,11]$. In particular, there is a need to address the social and cultural causes of highly energy demanding practices linked to television watching, which have been enabled by the acquisition of new internet-connected ICT devices driven by marketing, social networks and the offers of service providers [41].

A key element in understanding residents' energy practices is the need for 'comfort', as daily energy habits (e.g. cooking, cleaning, eating, and relaxing), linked to various technologies, are performed to meet comfort levels in households. While research has mainly focused on the technical and standardised concept of comfort (i.e. 'thermal comfort'), this concept has not been applied to how the use of home entertainment devices can satisfy residents' comfort expectations while conserving electricity in the home. 
Reducing energy consumption from ICT devices in households requires the combined intervention of various actors, including government, manufacturers, retailers and consumers [13]. For example, the IEA [76] proposes that governments should regularly update mandatory energy performance standards for electronic appliances, which should accurately represent the actual energy use of a device and be aligned with international test standards [83]. In addition, the introduction of a compulsory Energy Star rating scheme would ensure that only products certified to be energy efficient are sold by retailers [8]. Beyond governments, manufacturers have a critical role to play in continually seeking to introduce new, more energy efficient products into the market, in particular through increased research and development into 'smart appliances', which utilise ICT within devices to maximise energy efficiency and match product use with user needs (EST, 2007, POST, 2008). Retailers should supply products with clear information on their power consumption, i.e. through Energy Star or Energy Saving Recommended labels, and train staff to advise customers how to interpret such labels and help them to make purchase decisions based at least in part on the relative energy efficiency of items in their product range (EST, 2007). An ongoing challenge in this respect is consumers' poor understanding of units of electricity use such as watts, and the difficulty of translating these units to prices due to variable charges for electricity per household, dependent on the energy supplier and fluctuating energy prices (POST, 2008). Consumers can contribute themselves by seeking to purchase ICT entertainment appliances with the aforementioned labels, and actively seeking to reduce the standby use of such products, for example through power saving technology (EST, 2007). While energy efficiency is important, there is also a need to educate consumers about the impact of the number of devices they own on their energy consumption (Ropke et al, 2010).

In this paper, we also argue that certain policy interventions could be targeted at residential consumers, which aim to reduce domestic electricity demand more generally (i.e. not just from ICT), through feedback and environmental education for household energy consumption. Certainly in the case of feedback, empirical studies indicate that these strategies can achieve modest electricity savings. Nevertheless, public information campaigns disseminating energy savings tips for the purchase and use of entertainment appliances could help to make feedback approaches more effective. 
With respect to specific measures targeted at ICT equipment, regulations are in place to continually improve their energy efficiency, in particular the Eco-design and EU Labelling Directives. Additionally, voluntary schemes such as Energy Star provide a standard for the most efficient electronic devices in the market which could contribute even more effectively if all ICT products were required to comply with such schemes. Nevertheless, efficiency gains may be compensated by the rebound effect in the ICT sector, not least through the increased ownership and use of devices $[67,73,75]$.

However, policies which aim to increase ICT device efficiency are unlikely to be effective on their own, unless they are supported by solutions which account for new social practices related to the use of ICT so that residential electricity savings might be achieved. One such approach could involve tailored feedback together with goal setting for household electricity savings, considering specific consumption profiles and the needs of occupants. An alternative technology-led solution could be the use of ICT to help householders manage their energy consumption, while a 'smart' TV could also act as a central hub to encourage practices which meet occupants' comfort and entertainment needs using fewer devices.

\section{REFERENCES}

[1] Røpke, I., \& Christensen, T. H. Energy impacts of ICT - Insights from an everyday life perspective. Telematics and Inform 2012; 29: 348-61.

[2] IEA - International Energy Agency. Gadgets and Gigawatts. Policies for Energy Efficient Electronics; 2009. Report. International Energy Agency, Paris, France.

[3] Erdmann, L., Hilty, L. M. Scenario analysis: exploring the macroeconomic impacts of information and communication technologies on greenhouse gas emissions. J of Industrial Ecol 2010; 14: 826-43.

[4] Kalimaris, A., Kalluri, B., Kondepudi, S., Wai, T. K. A literature survey on measuring energy usage for miscalleneous electric loads in offices and commercial buildings. Renew and Sustain Energy Rev 2014; 34: 536-50.

[5] Bhandari, K.P., Collier, J.M., Ellingson, R.J., Apul, D.S. Energy payback time (EPBT) and energy return on energy invested (EROI) of solar photovoltaic 
systems: A systematic review and meta-analysis . Renew and Sustain Energy Rev 2015; 47: 133-41.

[6] Whitmarsh, L., Upham, P., Poortinga, W., McLachlan, C., Darnton, A., DevineWright, P., Demski, C., et al. Public Attitudes, Understanding, and Engagement in Relation to Low Carbon Energy: A Selective Review of Academic and Non Academic Literatures; 2011. Report for Research Council UK (RCUK) Energy Programme. Swindon: Research Councils UK.

[7] Stephenson, J., Barton, B., Carrington, G., Gnoth, D., Lawson, R., \& Thorsnes, P. Energy cultures: A framework for understanding energy behaviours. Energy Policy 2010; 38, 6120-29.

[8] Coleman, M., Brown, N., Wright, A., Firth, S.K. Information, communication and entertainment appliance use-Insights from a UK household study. Energy and Build 2012; 54: 61-72.

[9] McNeil, M.A., Letschert, V.E. Modeling diffusion of electrical appliances in the residential sector, Energy and Build 2010; 42: 783-90

[10] Santiago, I., López-Rodríguez, M.A., Gil-de-Castro, A. Moreno-Munoz, A., Luna-Rodríguez, J.J. Energy consumption of audiovisual devices in the residential sector: economic impact of harmonic losses. Energy 2013; 60: 292-301.

[11] Santiago, I., Lopez-Rodriguez, M. A., Trillo-Montero, D., Torriti, J., MorenoMunoz, A. Activities related with electricity consumption in the Spanish residential sector: Variations between days of the week, Autonomous Communities and size of towns. Energy and Build 2014; 79: 84-97.

[12] Energy Saving Trust (EST). The rise of the machines. A review of energy using products in the home from the 1970s to today; 2006. Report by EST.

[13] Energy Saving Trust (EST). The ampere strikes back - How consumer electronics are taking over the world report; 2007. Report by EST.

[14] Mansouri, I., Newborough, M., Probert, D. Energy Consumption in UK Households: Impact of Domestic Electrical Appliances. Appl Energy 1996; 54(3): 211-85.

[15] Kelly, G. Sustainability at home: Policy measures for energy-efficient appliances. Renew and Sustain Energy Rev 2012; 16: 6851-60.

[16] Firth, S., Lomas, K., Wright, A., Wall, R. Identifying trends in the use of domestic appliances from household electricity consumption measurements. Energy and Build 2008; 40 (5): 926-36. 
[17] Koomey, J.G. Power levels in office equipment: Measurements of new monitors and personal computers; 2002. American Council for an Energy-Efficient Economy (ECEEE), Washington DC: US.

[18] E3-Equipment Energy Efficiency. Third Survey of Residential Standby Power Consumption of Australian Homes; 2011. Prepared by Energy Efficient Strategies Pty Ltd. Common wealth of Australia. 〈file://C:/Users/dj837169/Downloads/E32010-Intrusive-Survey-FINAL-Report.pdf) (Accessed on $26^{\text {th }}$ December 2014).

[19] Centre for Sustainable Energy (CSE). Home energy advice; 2014. 〈http://www.cse.org.uk/downloads/advice-leaflets/energyadvice/advice_leaflet_what_uses_watt.pdf) (Accessed on $15^{\text {th }}$ May 2015)

[20] Energy Star. Energy Star Most Efficient 2015 - Televisions; 2015. 〈http://www.energystar.gov/index.cfm?c=most_efficient.me_tvs_under35_inches» (Accessed on $7^{\text {th }}$ January 2015).

[21] Williams, D. R. Modelling and assessing the environmental impacts of software. Engineering Doctorate (EngD) Thesis. Technologies for Sustainable Built Environments (TSBE) centre, University of Reading, Reading, UK; 2013.

[22] IEA - International Energy Agency. Energy Technology Perspectives: Scenarios and Strategies to 2050; 2006. Report. International Energy Agency, Paris, France.

[23] Cabeza, L.F., Urge-Vorsatz, D., McNeil, M.A., Barreneche, C., Serrano, S. Investigating greenhouse challenge from growing trends of electricity consumption through home appliances in buildings. Renew and Sustain Energy Rev 2014; 36: 188-93.

[24] Natural Resources Defense Council (NRDC). The impact of consumer electronics on home electricity use; 2011. 〈https://www.energystar.gov/ia/ partners/downloads/meetings/2011/Market\%20Trends\%20for\%20CE_Horowitz.p df) (Accessed on $14^{\text {th }}$ February 2015).

[25] Mills, M. The cloud begins with coal: Big data, big networks, big infrastructure, and big power; 2013. An overview of the electricity used by the global digital ecosystem. Report by the Digital Power Group. 〈http://www.tech-pundit.com/wpcontent/uploads/2013/07/Cloud_ Begins_With_Coal.pdf>(Accessed on $15^{\text {th }}$ February 2015).

[26] Lapillonne, B., Sebi, C., Pollier, K., Mairet, N. Energy efficiency trends in buildings in the EU; 2012. Lessons from the ODYSSEE MURE project. Intelligent Energy Europe Programme of the European Union. 
[27] Lapillonne, B., Pollier, K. Energy efficiency trends for households in the EU; 2014. Enerdata - ODYSSEE MURE project. Intelligent Energy Europe Programme of the European Union.

[28] Bertoldi, P., Hirl, B., Labanca, N. Electricity Consumption and Efficiency Trends in the EU-27. Energy Efficiency Status report; 2012. JRC Scientific and Policy Reports.

[29] Energy Saving Trust (EST). Powering the Nation. Household electricity - using habits revealed; 2014. Report by EST - Department of Energy \& Climate Change (DECC) - Department for Environment Food \& Rural Affairs (DEFRA).

[30] Gram-Hanssen, K. Consuming technologies - developing routines. J of Clean Product 2008; 16: 1181-89.

[31] Bray, M. Review of computer energy consumption and potential savings; 2006. White paper.

[32] Energy Star. Computers for Consumers; 2011a. Washington, US.

[33] Energy Star. Displays Product List; 2011b. Washington, US.

[34] Guan, L., Berrill, T., Brown, R. J. Measurement of standby power for selected electrical appliances in Australia. Energy and Build 2011; 43: 485-90.

[35] De Almeida, A., Fonseca, P., Schlomann, B., Feilberg, N. Characterization of the household electricity consumption in the EU, potential energy savings and specific policy recommendations. Energy and Build 2011; 43(8): 1884-94.

[36] Energy Saving Trust (EST). Brits could save $£ 1.7$ billion a year by switching appliances off standby; 2014. 〈http://www.energysavingtrust.org.uk/news/britscould-save-\%C2\%A317-billion-year-switching-appliances-standby> (Accessed on $29^{\text {th }}$ December 2014).

[37] Spigel, L. Domestic Technologies and the Modern Home. In: Smith, S. (Ed.) International Encyclopedia of Housing and Home, Elsevier; 2012, p.383-98.

[38] Boddy, W. New Media and the Popular Imagination: Launching Television, Radio, and Digital Media in the United States. Oxford University Press USA, North Caroline \& New York; 2004.

[39] FRA - Fraunhofer Institute for Reliability and Microintegration, IZM and ÖkoInstitut. EuP Preparatory Studies Lot 5: Televisions; 2007. Final Report on Task 2: Economic and Market Analysis, Berlin.

[40] Bertoldi, P., Atanasiu, B. Electricity Consumption and Efficiency Trends in European Union; 2009. Status Report. 
[41] Crosbie, T. Household energy consumption and consumer electronics: The case of television. Energy Policy 2008; 36: 2191-199.

[42] Cooper, T. Inadequate Life? Evidence of Consumer Attitudes to Product Obsolescence. J of consum policy 2004; 27(4): 421-49.

[43] Mont, O., Power, K. Understanding factors that shape consumption; 2009. ETC/SCP Working Paper No 1/2013. European Topic Centre on Sustainable Consumption and Production, Copenhagen.

[44] Pantzar, M. Shove, E. Temporal rhythms as outcomes of social practices. A speculative discussion. Ethnol Europaea 2010; 40: 19-29.

[45] Office for National Statistics (ONS). Record proportion of people in employment are home workers; 2014. 〈http://www.ons.gov.uk/ons/rel/lmac/characteristics-ofhome-workers/2014/sty-home-workers.html (Accessed on $15^{\text {th }}$ December 2014).

[46] Abrahamse, W, Steg, L, Vlek, C, Rothengatter, T. A review of intervention studies aimed at household energy conservation. J of Environ Psychol 2005; 25: 273-91.

[47] Darby, S. The effectiveness of feedback on energy consumption - A review for DEFRA of the literature on metering, billing and direct displays; 2006. Environmental Change Institute, University of Oxford.

[48] Fischer, C. Feedback on household electricity consumption: a tool for saving energy? Energy Effic 2008; 1(1): 79-104.

[49] Roberts, S., Baker, W. Towards effective energy information: Improving consumer feedback on energy consumption; 2003. A report to OFGEM (www.cse.org.uk).

[50] Buchanan, K., Russo, R., Anderson, B. Feeding back about eco-feedback: How do consumers use and respond to energy monitors? Energy Policy 2014; 73: 13846.

[51] Mills, B., Schleich, J. Residential energy-efficient technology adoption, energy conservation, knowledge, and attitudes: An analysis of European countries. Energy Policy 2012; 49: 616-628.

[52] Steg, L. Promoting household energy conservation. Energy Policy 2008; 36(12): 4449-53.

[53] Ellegard, K., Palm, J. Visualizing energy consumption activities as a tool for making everyday life more sustainable. Appl Energy 2011; 88: 1920-26. 
[54] European Environmental Agency (EEA). Achieving energy efficiency through behaviour change: what does it take?; 2013. EEA Technical Report - No 5/2013. Luxembourg.

[55] Pothitou, M., Kolios, A. J., Varga, L., Sai, G. A framework for targeting household energy savings through habitual behavioural change. Intern J of Sustain Energy 2014; 1-15. doi: 10.1080/14786451.2014.936867.

[56] eSESH. Saving Energy in Social Housing with ICT - Project Status Report; 2013. 〈http://esesh.eu/fileadmin/eSESH/download/documents/eSESH_Final_Report.pdf〉 (Accessed on $5^{\text {th }}$ February 2015).

[57] Australian Government. Your Energy Savings. Department of Industry and Science; 2015. 〈http://yourenergysavings.gov.au/> (Accessed on $9^{\text {th }}$ January 2015).

[58] Webb, D., Soutar, G.N., Mazzarol, T., Saldaris, P. Self-determination theory and consumer behavioural change: Evidence from a household energy-saving behaviour study. J of Environ Psycho 2013; 35: 59-66.

[59] Fell, M. J. Chiu, L. F. Children, parents and home energy use: Exploring motivations and limits to energy demand reduction. Energy Policy 2014; 65: 351358.

[60] Vicente-Molina, M. A., Fernández-Sáinz, A., Izagirre-Olaizola, J. Environmental knowledge and other variables affecting pro-environmental behaviour: comparison of university students from emerging and advanced countries. $\mathrm{J}$ of Clean Prod 2013; 61: 130-138.

[61] Uzzell, D. Children as Catalysts of Environmental Change; 1994. Brussels, European Commission. 〈http://www.academia.edu/1131741/Children_as_Catalysts_ of_Environmental_Change> (Accessed on 20 $0^{\text {th }}$ November 2014).

[62] Palmer, J., Terry, N., Armitage, P., Godoy-Shimizu, D. Savings, beliefs and demographic change - Further Analysis of the Household Electricity Survey; 2014: 4-69. Reference 475/09/2012.

[63] Palmer, J., Terry, N., Kane, T., Firth, S., Hughes, M., Pope, P., Young, J., Knight, D., Godoy-Shimizu, D. Electrical appliances at home: tuning in to energy saving - Further Analysis of the Household Electricity Use Survey; 2013: 3-146. Reference 475/09/2012. 
[64] European Commission (EC). Helping consumers reduce energy bills and save money; 2015.

〈http://ec.europa.eu/unitedkingdom/press/frontpage/2014/14_138_en.htm〉

(Accessed on $11^{\text {th }}$ February 2015).

[65] Parliament UK. Incandescent Light Bulbs. Daily Hansard; 2012. 〈http://www.publications.parliament.uk/pa/cm201213/cmhansrd/ cm120522/halltext/120522h0002.htm> (Accessed on $7^{\text {th }}$ January 2015).

[66] CTIA. CTIA’s Wireless Industry Survey, year-end 2013; 2014. 〈http://www.ctia.org/docs/default-source/FactsStats/ctia_survey_ye_2013_graphics-final.pdf?sfvrsn=2> $\left(\right.$ Accessed on $15^{\text {th }}$ February 2015).

[67] Organisation for Economic Co-operation and Development (OECD). Greener and Smarter: ICTs, the Environment and Climate Change; 2010. Committee for Information, Computer and Communications Policy (ICCP). 〈http://www.oecd.org/site/stitff/45983022.pdf〉 (Accessed on $25^{\text {th }}$ January 2015).

[68] Eurofound. Fifth European Working Conditions Survey - Overview report; 2012. Publications Office of the European Union, Luxembourg. 〈http://www.eurofound.europa.eu/publications/htmlfiles/ef1182.htm〉 (Accessed on $22^{\text {nd }}$ August 2014).

[69] Maxwell, D, Owen, P., McAndrew, L., Muehmel, K., Neubauer, A. Addressing the Rebound Effect; 2011. A report for the European Commission DG Environment.

[70] Bates, O., Hazas, M., Friday, A., Morley, J., Clear, A.K. Towards an holistic view of the energy and environmental impacts of domestic media and IT. Proceedings of the Conference on Human Factors in Computing, Toronto, Canada, $26^{\text {th }}$ April- $1^{\text {st }}$ May 2014, New York: ACM.

[71] Jensen, J.O., Gram-Hanssen, K., Røpke, I., Christensen, T.H. Households' use of information and communication technologies - A future challenge for energy savings?; 2009. In: Proceedings of ECEEE Summer StudyCote d'Azur, France.

[72] Røpke, I., Christensen, T.H., Jensen, J.O. Information and communication technologies - A new round of household electrification. Energy Policy 2010; 38: 1764-73.

[73] Department of Energy and Climate Change (DECC). Energy consumption in the UK (ECUK) domestic data tables; 2014. London: DECC. 
[74] Office for National Statistics (ONS). Families and Households; 2012.

〈http://www.ons.gov.uk/ons/rel/family-demography/families-andhouseholds/2012/stb-families-households.html (Accessed on $5^{\text {th }}$ June 2015).

[75] Terry, N., Palmer, J. Trends in home computing and energy demand. Build Res and Inform 2015; doi: 10.1080/09613218.2015.1040284 (in press).

[76] IEA - International Energy Agency. 25 Energy Efficiency Policy Recommendations: 2011 Update; 2011. International Energy Agency, Paris, France.

[77] Kwatra, S., Amann, J., Sachs, H. Miscalleneous Energy Loads in Buildings; 2013. Report Number A133, American Council for an Energy-Efficient Economy (ECEEE), Washington, DC: US.

[78] Schatzki, T.R. The site of the social. A philosophical account of the constitution of social life and change. The Pennsylvania State University Press, University Park, Pennsylvania; 2002.

[79] Kenyon, S. Internet use and time use. The importance of multitasking. Time and Soc 2008; 17: 283-318.

[80] Lord, C., Hazas, M., Clear, A.K., Bates, O., Whittam, R., Morley, J., Friday, A. Demand in my pocket: Mobile devices and the data connectivity marshalled in support of everyday practice; 2015. CHI '15 Proceedings of the $33^{\text {rd }}$ Annual ACM Conference on Human Factors in Computing Systems. Seoul, Korea.

[81] Ropke, I. Theories of practice - new inspiration for ecological economic studies on consumption. Ecol Econ 2009; 68: 2490-97.

[82] Abetti, P. The birth and growth of Toshiba's laptop and notebook computers: A case study in Japanese corporate venturing. J of Bus Venturing 1997; 12(6): 50729.

[83] Organisation for Economic Co-operation and Development (OECD). Can energy-efficeint electrical appliances be considered "Environmental Goods"?; 2006. OECD Trade and Environment Working Paper No. 2006-04.

[84] Kawsar, F., Brush, A.J. Home computing unplugged: Why, where and when people use different connected devices at home; 2013. Proceedings of the 2013 ACM International joint conference on Pervasive and ubiquitous computing, Zurich, Switzerland. 